\title{
衝撃プログラム荷重下における疲労強度および 疲労き裂の発生，進展についで
}

\author{
中山英 明** 金山幸 雄 ${ }^{* * *}$ 式田昌 弘***
}

\section{On Fatigue Strength and Fatigue Crack Propagation Behavior under Impact Program Load Condition}

by

\author{
Hideaki NAKAYAMA \\ (Faculty of Junior College of Automobile Industry, Osaka Industrial University, Daito) \\ Yukio Kanayama and Masahiro SHIKIDA \\ (Faculty of Engineering, Osaka Industrial University, Daito)
}

\begin{abstract}
As one of the investigations to reveal the effect of impact load on the fatigue behavior, i.e., fatigue life, fatigue crack initiation and propagation, a series of fatigue tests was conducted with a cantilever type rotating bending fatigue testing machine equipped with an impact loading device under two sorts of program load patterns; one is the impact program load condition in which the maximum bending stress followed by the transitional decaying vibrational load appears by an impact load at the rise time of the primary stress and another the ordinary periodical 2-step program load condition.

Here, annealed $0.23 \% \mathrm{C}$ carbon steel specimens with a small hole on the plane of the minimum sectional area were used to observe the behavior of fatigue crack initiation and propagation during the fatigue process. The experimental results were discussed from two points of view; the equivalent number of overstressing cycles and the cumulative damage in the modified Miner's rule concept.

From the comparison of the equivalent number of overstressing cycles for crack initiation with that for fatigue failure, it was concluded that the impact program load pattern like the one in this experiment is more detrimental to propagate fatigue cracks than to initiate those. Such a fatigue behavior in the impact program condition is also recognized from the discussion based on the cumulative damage in the modified Miner's rule concept, that is, the ratio of the cumulative damage for crack initiation to that for fatigue failure takes generally a higher value than the value in nonimpact fatigue load conditions.

(Received May 21, 1979)

キー・ワード：衝撃プログラム荷重, 定常プログラム荷重, 疲労き裂, 累積被害
\end{abstract}

\section{1 緒言}

実際の機械構造物の置かれるいわゆる実働荷重状態 を想定するとき, 過大忘力の作用は極めて小頻度であ り，またこの過大応力が衝撃的に作用する場合のある ことは例えば鉄道車輛の車軸など関して良く知られ ているところである.こうしたことより，筆者らの一 人は以前より衝撃荷重下での金属材料の疲労挙動汇着 目し, 引張圧縮両振荷重下での系統的な衛撃疲労研究 を行い,そこに和いて強度面扣よび非弾性ひずみ挙動 の側面よりなる衝撃疲労特性を明らかにしてきたが, 特に強度特性として衝撃荷重下では通常の正弦波荷重

* 原稿受理 昭和 54 年 5 月 21 日

** 正 会 員 大阪産業大学短期大学部 大東市中垣内

*** 正会員大阪産業大学工学部大東市中垣内
下に比して疲労強度の低下を生じることを示した。

さて, 衝撃荷重を含む実働荷重条件下での金属材料 の疲労問題を考学るに際して, 衝撃荷重が連続的に作 用する場合々通常の非衝撃性荷重の中に間欠的に作用 する場合の二種の条件が考兄られ，例兄ば機珹式プリ ンタの印字ハンマーのようと打撃機構とのものを基本 的作動とする機械構造物を除外すれば，特に工業的観 点より後者の場合に括ける疲労挙動化関する知見を有

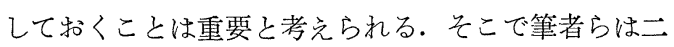
段多重回転曲げ荷重を基本荷重とし，これに衝撃荷重 が重畳した場合の疲労挙動を調べるため一連の研究を 計画し，得られた結果のいくつかについては既に報告 してきた。本報告になる研究は横穴付さ試験片を用い

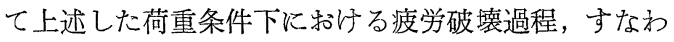


ら疲労き裂の発生進展挙動を調べたものである.

ここで, 衝撃プログワム荷重条件下においては実験 技術上の制約もあり，き裂発生筃所としてもら㞴た横 穴の位置と衝撃傎荷サイクルが同期していないため， 横穴近傍の応力履歴はかなり複雑なものとなっている。 そこでこの種の荷重条件下での結果を整理するに際 してはみかけの応力変動家採用し,これより衝撃負荷 の効果について検討を加觉た。こうした評価法は疲労 破壞簀所の応力状態を正確に表現していない意味で幾 分の問題ばあるが，本実験において生じる現象を巨視 的な意味で評価するための一つの簡便法としてここで は用いた。

本研究の結果を上記の手法で評価した場合，通常の 一段多重プログラム疲労試験結果との比較に和いて衝 撃負荷が特に疲労き裂の進展過程でこれを促進される 形で顕著に作用することが明らかとなったので，以下， これについて詳述する。

\section{2 供試材 料}

本実験に使用した材料は $0.23 \%$ C 炭素鎙であり，そ の化学成分を Table I K, 蓺処理条件就よ゙゙静引張 試験での㙨械的性質を Table II に示している。材料 ばすべて $\phi 20$ 熱間压延鋼として供給されたものであり， 所定の熱処理ののち, Fig. 1 飞示す試戨片の形状, 寸 法に機械加工乙実験に供した。Fig.1 にみるように試 験片最小断面部に疲労き裂発生簓所学限定するだめ值 径 $0.3 \mathrm{~mm}$, 深さ1 $\mathrm{mm}$ の一つの横穴をドリル加工し ているが，応力の算定にあたっては横穴による断面積 減少分は考慮していない。

\section{3 実験装置および実験方法}

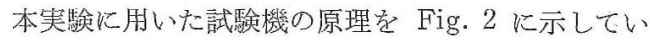
るが，図にみるように本装賢は通常の片持回転曲げ疲

Table I. Chemical composition of the material.

\begin{tabular}{l|c|c|c|c|c|c|c}
\hline \multirow{2}{*}{ Material } & \multicolumn{6}{|c}{ Chemical composition (\%) } \\
\cline { 2 - 7 } & $\mathrm{C}$ & $\mathrm{Si}$ & $\mathrm{Mn}$ & $\mathrm{P}$ & $\mathrm{S}$ & $\mathrm{Ni}$ & $\mathrm{Cr}$ \\
\hline $\mathrm{S} 25 \mathrm{C}$ & 0.23 & 0.26 & 0.52 & 0.013 & 0.022 & 0.02 & 0.02 \\
\hline
\end{tabular}

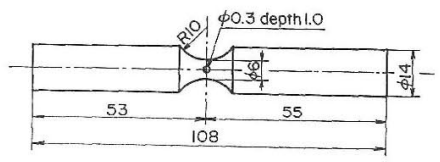

Fig. 1. Shape and sizes of the specimen.

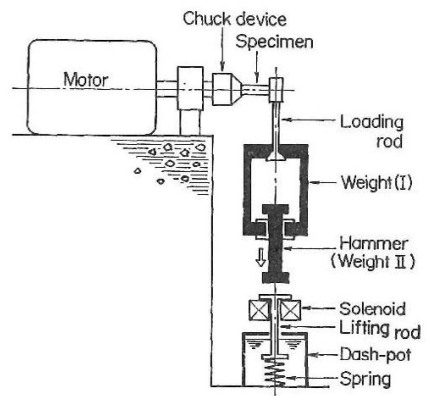

Fig. 2. Principle of the rotating bending fatigue testing machine equipped with the impact loading device.

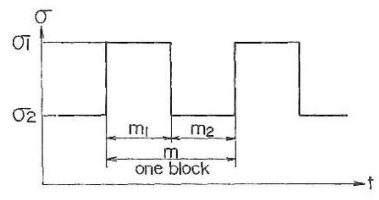

(a) Ordinary program load pattern

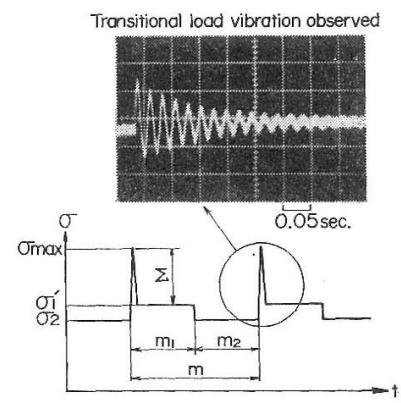

(b) Impact program load pattern

Fig. 3. Schematic representation for the ordinary and the impact program load patterns.

労試験機に衝撃負荷装置を組み合わせたもので京り， 既報に詳述したよらにハンマー（重すいII）の作動状 熊を適当に調節することにより，通常の二段多重プロ グラム荷重条件（以下，定常プログラムと呼ぶ）和よ び 1 次応力への立ら上がり時に衝撃荷重による過渡振 動荷重を含さプログラム荷重条件（以下，衝撃プログ ラム）が得られる.上記 2 種のプログラム荷重の様子 をFig. 3 に模式的に示しているが，図中に併过示す負 荷棒に貼付したひずみゲージより検出した減衰振動荷

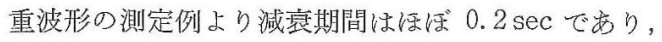
この期間中の荷重サイクルは10サイクルを越党ないこ とが認められた。 采た隇衰振動周波数 $f_{e}$ は約 $40 \mathrm{~Hz}$ となり, 試験片回転速度 $f_{m}=60 \mathrm{~Hz}$ との関連より減哀

Table II. Heat treatment and mechanical properties of the material.

\begin{tabular}{|c|c|c|c|c|c|c|}
\hline Heat treatment & $\begin{array}{l}\text { Upper yicld } \\
\text { point } \\
\sigma_{\text {SSo }}\left(\mathrm{kg} / \mathrm{mm}^{2}\right)\end{array}$ & $\begin{array}{l}\text { Lower yield } \\
\text { point } \\
\sigma_{S U}\left(\mathrm{~kg} / \mathrm{mm}^{2}\right)\end{array}$ & $\begin{array}{l}\text { Ultimate tensile } \\
\text { strength } \\
\sigma_{B}\left(\mathrm{~kg} / \mathrm{mm}^{2}\right)\end{array}$ & $\begin{array}{c}\text { Breaking strengih } \\
\text { on final area } \\
\sigma_{T}\left(\mathrm{~kg} / \mathrm{mm}^{2}\right)\end{array}$ & $\begin{array}{c}\text { Elongation } \\
\delta(\%)\end{array}$ & $\begin{array}{l}\text { Reduction of } \\
\text { area } \\
\varphi(\%)\end{array}$ \\
\hline $900^{\circ} \mathrm{C}, 1 \mathrm{hr}$, F.C. & 30.5 & 26.1 & 42.9 & 85.2 & 42.8 & 62.1 \\
\hline
\end{tabular}




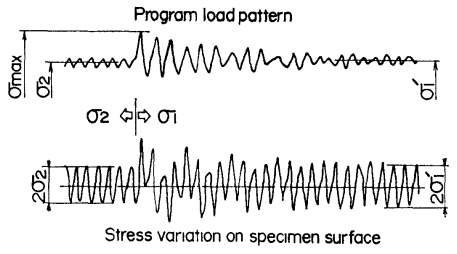

Fig. 4. Stress variation on the specimen surface measured with strain gage mounted on the specimen.

過程で試験片に生じる曲げ応力変動は次式で表される. すなわち，

$$
\sigma(t)=\left(\sigma_{1}^{\prime}+\Sigma e^{-\alpha t} \sin 2 \pi f_{c} t\right) \cos \left(2 \pi f_{m} t+\varphi\right)
$$

ここに， $\sigma_{1}{ }^{\prime}$ は一定とされる衝撃プログラム中の 1 次 応力の大きさ $\left(=13.4 \mathrm{~kg} / \mathrm{mm}^{2}\right) ， \Sigma$ は衝撃負荷によ る応力の増分， $\varphi$ は試験片表面上での位置に関する初 期位相，また $\alpha$ は減衰係数であり本実験の場合には約 7.7 の值をとった.

さて, Fig. 4 は試験片表面にひずみゲージを貼付し, 試作した水銀接点式スリップリングを介して測定した 衝撃負荷後減衰過程での応力変動の一例をプログラム 荷重変動との対応で示したものである. 図に久るよう に，衝撃プログラム条件下に和訬る試験片表面上での 応力変動は複雑な形態を示し，その様子はまた(1)式に みるよらに初期位相 $\varphi$ により異り，さらに試験片回転 速度と衝撃負荷サイクルを同期させていないため，各 衝撃負荷ごとに Fig. 3 (b) に示すような応力変動が試 験片上の同一籄所に生じるとは限らず，試験片はかな クランダムな応力状態に扣かれているものと推察され る。このような場合には試験片表面上の各箇所飞おけ る応力変動によるよりもむしろ負荷条件を明示した形 で Fig. 3 中にその測定例を示したようなみかけの応 力変動に依拠した簡潔な応力パラメータを用いて便宜 的に実験結果を評価するのも一手法之判断され，次章 以下に扔いてはそらした手法により衝撃プログラム疲 労試験結果に対する考察を行っている.

本試験機に打いてはハンマーの落差を調節すること により種々の大きさの最大応力 $\sigma_{\max }\left(=\sigma_{1}{ }^{\prime}+\Sigma\right)$ をも つ衝撃プログラム荷重が得られるが，本実験では $\sigma_{\max }=33.4,31.0,25.0$ 㧊よび $21.0 \mathrm{~kg} / \mathrm{mm}^{2}$ の条 件下で衝撃プログラム疲労試験を行い, 一方, 定常プ ログラム疲労試験は 1 次応力 $\sigma_{1}=25.0,21.0,18.0$ 特よび $16.0 \mathrm{~kg} / \mathrm{mm}^{2}$ の条件下で行った.

ここで，両プログラム条件下ともに 2 次応力 $\sigma_{2}$ の 大ささ㧊よび 1 次応力の作用期間 $m_{1}$ は一定であり， それぞれ $\sigma_{2}=11.0 \mathrm{~kg} / \mathrm{mm}^{2}, m_{1}=2 \mathrm{sec}$. とした。 また， プログラム周期 $m$ については $m=4,10,60$ sec.の 3 種を採用した。なお，Fig. 3 にみたように，衝撃プロ グラム条件下での 1 次応力の作用期間には最大応力に
続く減衰振動応力と定常的 1 次応力 $\sigma_{1}{ }^{\prime}$ が含まれる.

さらに,き裂長さの検出はアセチルセルロースフィ ルムを用いて横穴近傍のレプリカを採取し，これを光 学顕微鏡で測定することにより行ったが，ここでは横 穴の径を含む全長をもってき裂長さ $l$ を定義し，き裂 長さ $l$ が $0.4 \mathrm{~mm}$ に達した時点をもってき裂発生とみ なした。

\section{4 実験結果および考察}

$0.23 \% \mathrm{C}$ 炭素鋼焼なまし材よりなる横穴切欠き付試 験片を用いて行った衝撃プログラム疲労試験に扣ける 疲労破断寿命および疲労き裂の発生, 進展挙動を対応 するプログラムパラメータを有する定常プログラム条 件下でのそれらと比較しながら，衝撃負荷の影響につ いて以下検討を加觉るが，その際には既述のように， 衝撃プログラム条件下において試験片横穴切欠き部は 各ブロックごとに Fig. 3 (b) に示したような 最大応力 $\sigma_{\max }$ に継続する減衰荷重振動を受けるものと仮定し ている.

\section{$4 \cdot 1$ 衝撃プログラム荷重下での強度特性}

まず，定荷重下での疲労試験結果を示す Fig. 5 よ り, 横穴付き試験片の疲労限度は約 $15.0 \mathrm{~kg} / \mathrm{mm}^{2}$ であ り，平滑材と記している横穴なし試験片による強度と の比較より横穴による切欠さ係数 $\beta$ は約 1.5 の值をと る.なお，図中には既述の定義に基づき後出の Fig. 9 より求められたさ裂発生に対する $S-N$ 曲線も併せ示 しているが，以下これら 2 本の $S-N$ 曲線をそれぞれき 裂発生叔よび破断寿命に対する基本 $S-N$ 曲線と呼ぶ. 次いで，両プログラム条件下での実験結果を Fig. 6 に示しているが，図の横軸には過大応力繰返し数とし て 1 次応力繰返し数 $N_{1 f}$ および衝撃 プログラム条件 下についてはブロック数 $Z_{f}$ をとって抒り，また図中 に細線で示すのは基本 $S-N$ 曲線である.

図より，衝撃プログラム条件下での結果は定常プロ グラム条件下でそれに比してかなり低繰返し数側に位 置していることが観察されるが，こうしたことはまず ここで無視された減衰期間に含まれる数サイクルの過 大応力の効果によるものと考光られる. そこで, 1 次

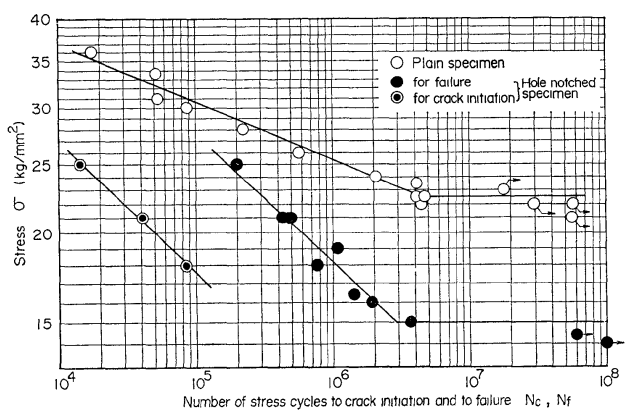

Fig. 5. $S-N$ curves under constant load condition. 


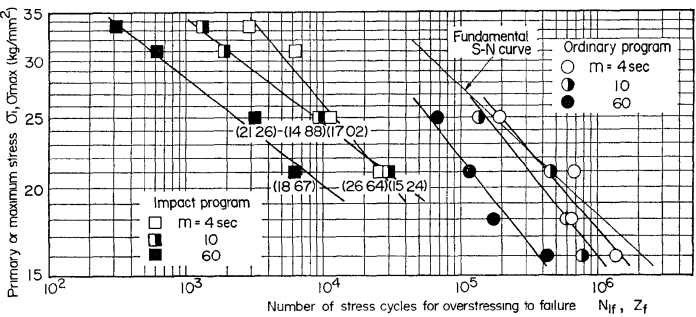

Fig. 6. $S-N$ curves for overstressing under two sorts of the program load conditions.

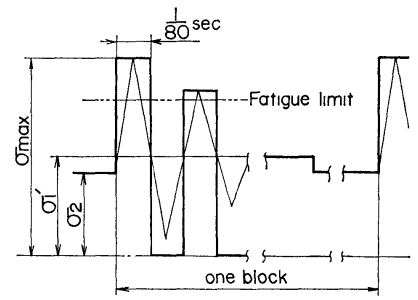

Fig. 7. Approximation to multi-steps program load pattern.

応力と最大応力の大きさが同等である 2 種の応力レベ ルについて両プログラム条件下での強度を対応させる に衝撃プログラム条件下においてどれ注どの最大応力 の繰返し数が要求されるか, 換言すれば最大応力の等 価繰返し数を算出したが，その結果を衝撃プログラム 荷重下での実験点の下に括孤をつけて示している。 こ れらの数値の平均値として約19.0サイクルが得られる が，このことは既述の減衰挙動とはかなり隔たって拉 り，減衰振動域をすべて最大応力作用期間とみなして もこらした荷重条件下での疲労寿命に対しては過小な 評価を与え，適正な寿命評価をなし兄ないことを示し ている.

さて, 実際の減衰振動荷重をFig. 7 にその説明図 を示すような多段プログラム荷重に近似し，これに基 づき 3 種の方法,すなわち第 1 ピーク近似法，マイナ 一則拈よび修正マイナー則により求めた破断までの累 積被害をそれぞれ $D_{1}, D_{2}$ 扰よび $D_{3}$ としてプログラ ム周期 $m$ に対して示したものが Fig. 8 である.なお゙, 図において応力の大きさを 1 次応力 $\sigma_{1}$ で表示してい るもの（丸印）は定常プログラム条件下での結果であ り, 一方, 最大応力 $\sigma_{\max }$ によるもの (四角印) は衝 撃プログラム条件下でのそれである。

図上りまず, $D_{1}$ 特よび $D_{2}$ として求められている衝 撃プログラム条件下での結果より，減衰域に含まれる 過大応力成分による累積被害の值は小さいことが認め られ，次いで $D_{3}$ として示寸修正マイナー則による整理 結果より，定常プログラム条件下での結果は過小応力 による弱化効果を示しながらも良く 1 の回りに収束す る様子を示しているが, 一方, 衝撃プログラム条件下 に扮いては最大応力レベルの增加に伴い破断までの祘

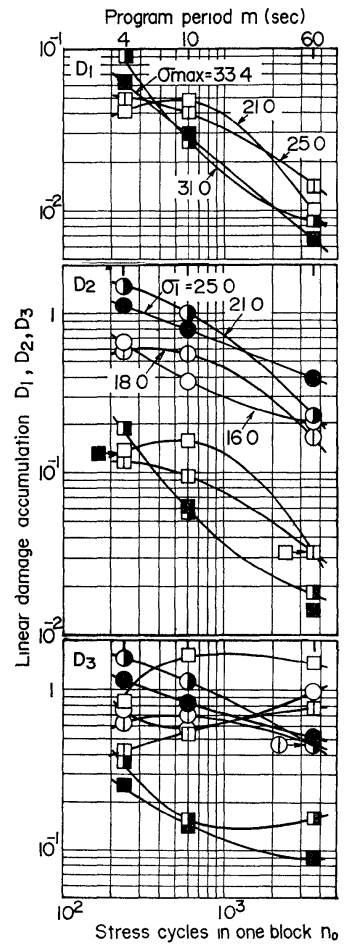

Fig. 8. Cumulative damage for failure by linear damage rule.

積量の低下する傾向が特徵的に観察される. 衝撃プロ グラム荷重下でのこうした特異な傾向については次節 に扔いてさらに検討を加えることとする。

なおここで，本章の冒頭に記述したように，衝撃プ ログラム条件下での応力条件に対して一定の仮定がと られていることから本節に述べたことは厳密な意味で 正確な定量的評価とはなり得ない。しかし，仮り飞詳 細な応力履歴を評価の基礎にす光たとするならば，よ り小さな累積被害の值をとり, 衝撃負荷の効果がより 顕著となることが予想され，なた Fig. 8 に対する評 価に際しても衝撃プログラム疲労試験結果の相対的関 係に対して影響は及ぼさない。こうしたことは次節に 述べられる疲労き裂の発生, 進展挙動に対する評価に 際しても同様であるのでここに付記して拈く。

\section{$4 \cdot 2$ 衝撃プログラム荷重下での疲労き裂の発生, 進展について}

Fig. 9 亿示す各荷重条件下での疲労き裂進展曲線に 基づき標記の観点より検討を加兄るが，以下示す図に おいては疲労き裂進展過程で遅延の様子を示した衝撃 プログラム条件下に和ける一つの実験結果 $\left(\sigma_{\max }=\right.$ $\left.31.0 \mathrm{~kg} / \mathrm{mm}^{2}, \quad m=4 \mathrm{sec}\right)$ についてはこれを一応除去

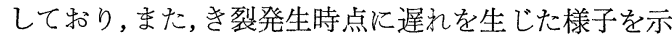
す定常プログラム条件下での結果 $\left(\sigma_{1}=16.0 \mathrm{~kg} / \mathrm{mm}^{2}\right.$, $m=60 \mathrm{sec}$. ) についてはこれを括孤付きで示している. 

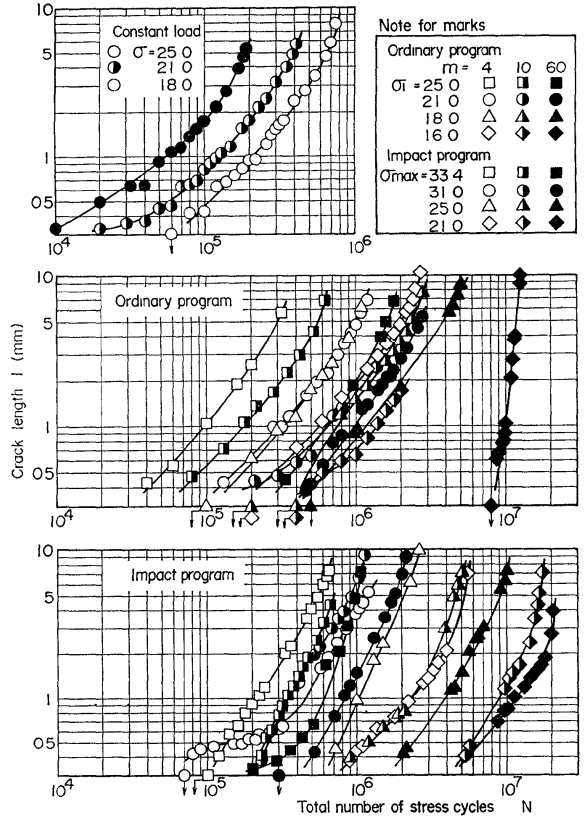

Fig. 9. Fatigue crack propagation curves.

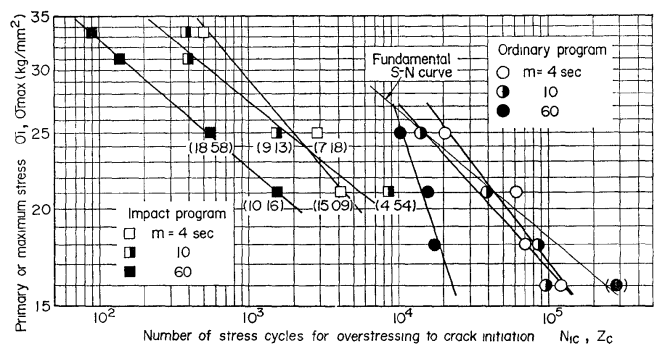

Fig. 10. Crack initiation curves for overstressing.

まず，Fig. 10 に示すのは過大応力のみを考慮した き裂発生に対する $S-N$ 曲線であり，図中細線で示す のはき裂発生に対する基本 $S-N$ 曲線である. 図にみ られる各荷重条件下での $S-N$ 曲線の相対的位置関係 は Fig. 6 に括けるそれと同様であるが，前述と同様 の考方方算出された衝撃プログラム条件下での最大 応力に対する等価繰返し数は Fig. 6 に示すとれらに 比して幾分小さな值をとっていることが観察され，い まこれらの平均值をとれば約10.8を得る.

次いで両プログラム条件下での疲労き裂進展挙動の 相違について 量的検討を加えるため, き裂長さが 1 $\mathrm{mm}$ から $3 \mathrm{~mm}$ の区間に関して両荷重条件下での 1 ブロックあたりの平均き裂進展速度を求めたが，その 結果を Fig. 11 に示している. 図中, 実験点の近傍に 添えた括孤の中の数值はFig. 6, むしくはFig. 10 に掠 けると同様の等価繰返し数であるが，Fig. 10 に示し たき裂発生に対する数值に比べてより大きな值をとっ て蚛り，これら両図より，本実験に和けるような形態

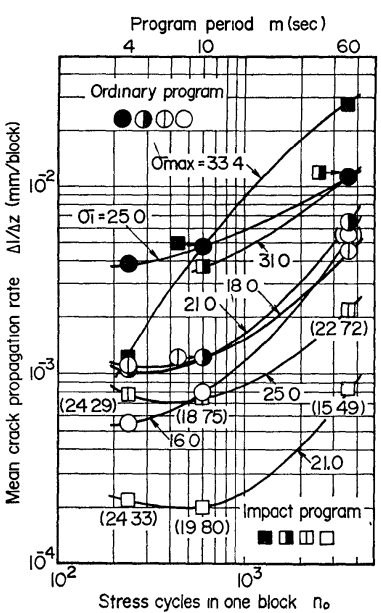

Fig. 11. Mean crack propagation rate in one block.

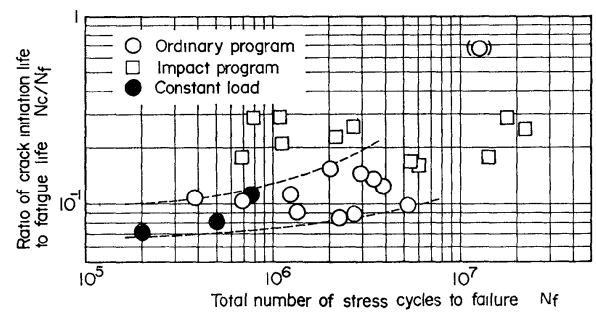

Fig. 12. Value of the ratio $N_{c} / N_{f}$ against the total number of stress cycles to failure.

の衝撃荷重は疲労き裂発生前後で影響の仕方が異り， 特に進展過程でそれを促進させる方向で顕著に作用す ることが認められる。

ここで, 両プログラム条件下でのき裂発生時期をみ るため, 総応力繰返し数に基づき, 破断寿命に対する き裂発生寿命の比 $N_{c} / N_{f}$ を破断寿命に対して示した ものが Fig. 12 である. 図にみるよらに, 定荷重下お よび定常プログラム荷重下に和けるこの比の值は破断 寿命の増加に伴い漸次増加する傾向を呈するのに対し， 衝撃プログラム荷重下に和けるそれは破断寿命に対し てほぼ一定な值を示しているが，特に破断寿命 $N_{f}=$ $10^{6}$ 回付近にみられるよらに, 衝撃プログラム条件下 に护方方が定常荷重条件下に比して大きなき裂発生 寿命比 $N_{c} / N_{f}$ をとることは衝撃荷重下での疲労さ裂 発生, 進展挙動を考兵るら劣で留意を要する点であろ 5 .

さて, 上述のことを過小応力効果を含めて考察する ため，各荷重条件下におけるき裂発生までの累積被害 $D_{c}$ 和よびき裂発生後破断までのその值 $D_{p}$ をそれぞれ 修正マイナー則により求め, それらの值を両対数紙上 に示したものが Fig. 13 である. ここで, 同図の作成 に際して定常プログラム条件下ではプログラム周期に よる傾向上の変化がみられたのでこれにより実験点 


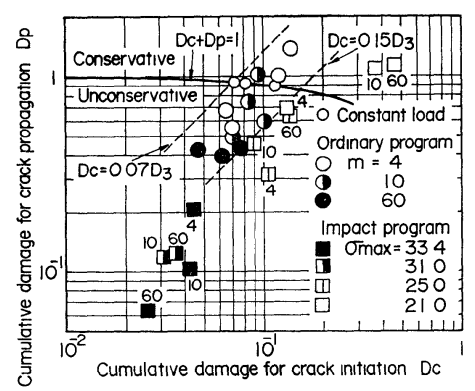

F1g. 13. Values of the cumulative damage for crack initiation $D_{c}$ and of that for propagation $D_{p}$.

記入上の分類を行い，一方，衝撃プログラム条件下で は最大応力扰よびプログラム周期ともに一定の変化傾 向を与えたので最大応力別に分類し, 周期 $m$ について は実験点に添字した。な技，図中には参考のためFig. 5 に示した定荷重下に抢けるこれらの值 $D_{c}$ 抢よび $D_{p}$ を小さな白丸で併せ示している.

まず，図より定荷重下拈よび定常プログラム条件下 での結果について，Fig. 8 に示した破断までの累積被 害 $D_{3}\left(=D_{c}+D_{p}\right)$ に対して $D_{c}$ がどの程度の割合を占 めるかをみるため，算出値の上，下限をとったばらつき 带を 2 本の破線で示しているが，これより定常荷重下 での $D_{c}$ 洼添ぼ $(0.07 \sim 0.15) D_{3}$ の範囲に収末ること が観察される.

次いで衝撃プログラム条件下での結果を定常荷重下 でのそれとの比較に打いてみると，全体として大きな 值の累積被害比 $D_{c} / D_{3}$ を要していることが 観察され, 上述された過大応力の夕に着目した等価繰返し数によ ると同様の評価が過小応力を評価した形でもなされう ることがわかる.

さらに, 過小応力効果に対応するプログラム周期 $m$ の影響についてみると, 衝撃プログラム疲労試駼結果 のらち比較的最大応力值の小さい場合にの及他の条件 下での傾向とは異り, 周期の大なるほど安全側に移行 する様子を示す。こうしたことは定常荷重下和よび比 較的大きな過大応力を伴う場合の衝撃プログラム条件 下と上述の場合とで過大応力作用時の疲労破壊核の生 成の仕方が異り，このことが過小応力効果を規定する ことによろと推察され，間欠的に衝撃負荷が作用する 場合の過小応力効果を考光るらえで留意すべき点を示 唆しているが, この種の現象については今後の研究の 中で明らかにして行きたい。

\section{5 結訔}

本研究は $0.23 \% \mathrm{C}$ 炭素鋼焼なるし材よりなる横穴付
き試験片を用いて定常プログラム条件下から衝撃プロ グラム条件下までの一連の回転曲げ疲労試験を行い， 疲労寿命および疲労き裂発生, 進展挙動に及ぼす衝撃 荷重の影響を調べたものである.

本研究で得られた主な結論は次のと抢りである.

(1) 両プログラム条件下での疲労寿命を過大応力に のみ基づき評価した場合，衝撃プログラム中の減衰期 間をすべて最大応力作用期間とみなしても衝撃プログ ラム疲労寿命に対しては過小な評価を与兄る.

（2）修正マイナー則により破断までの累積被害をと った場合，定常プログラム疲労試験結果は良く 1 の回 りに収束するが，衝撃プログラム条件下でのそれは最 大応力の上昇に伴い顕著な低下傾向を示す.

（3）定常プログラム条件下との対応より，疲労さ裂 発生までおよび進展過程における衝撃プログラム条件 下での最大応力の等価繰返し数を算出すると, 前者よ りも後者住対する方が大きな值を示したが，このこと より本実験にみるような衝撃荷重は特に進展過程で大 きな寄与をなすことが認められた。

（4）修正マイナー則に依拠して求めた疲労き裂発生 前後に䑙ける累積被害の相関性については，上の結論 (3)との関連より衝撃プログラム条件下ではき裂進展に 対する値 $D_{p}$ が小さな值をとることから全体としての 值 $D_{3}$ が減じ，このことより定常荷重条件下での結果 に比してみかけ上き裂発生までに大きな累積被害比 $D_{c} / D_{3}$ を要する。

叔わりに，本実験の遂行に際して熱心な協力を頂い た当時大阪産業大学工学部学生, 阿部邦彦, 五十嵐修 一，坂本正実，清水俊一の諸君に記して謝意を表する。

また，本研究の一部に昭和 54 年度文部省科学研究費 補助金（奨励研究 $\mathrm{A}$, 課題番号 475081）を使用したの で付記して謝意を表する。

（昭和54年 5 月 23 日 日本材籵学会第28期総会学術講寅会にて講窗）

\section{参 考 文 献}

1) 例えば, 中村 宏, 材料, 16, 71 (1967).

2）例えば，田中道七，中山英明，材料，23，678（1974）。

3) Nakayama, H., and T. Tanaka, Bulletin of the Institute for Industrial Research of O.I. U., No. 2, 93 (1979).

4）中山英明，金山幸雄，式田昌弘，阪産大論集，No. 50, 21 (1977).

5）中山英明, 金山幸雄, 式田昌弘, 材料, 28, 112 (1979).

6) Nakayama, H., Y. Kanayama, and M. Shikida, 22 nd Japan Congr. Mat. Res, Proc., 187 (1979). 